\title{
Quick Decline Disease Disturbs the Levels of Important Phytochemicals and Minerals in the Stem Bark of Mango (Mangifera indica)
}

\author{
Abdul Saeed, ${ }^{1}$ Muhammad Aslam Shad, ${ }^{1}$ Haq Nawaz, ${ }^{1}$ Mustafa Nawaz Shafqat, ${ }^{2}$ \\ Zahid Muneer, ${ }^{2}$ Aqeela Shaheen, ${ }^{3}$ and Syed Tahir Abbas Shah ${ }^{2}$ \\ ${ }^{1}$ Department of Biochemistry, Bahauddin Zakariya University, Multan 60800, Pakistan \\ ${ }^{2}$ Department of Biosciences, COMSATS Institute of Information Technology, Islamabad 45550, Pakistan \\ ${ }^{3}$ Department of Chemistry, The Islamia University of Bahawalpur, Bahawalpur 63100, Pakistan \\ Correspondence should be addressed to Syed Tahir Abbas Shah; syedtahirabbas@comsats.edu.pk
}

Received 9 November 2015; Revised 27 February 2016; Accepted 7 March 2016

Academic Editor: Manuel Tejada

Copyright (C) 2016 Abdul Saeed et al. This is an open access article distributed under the Creative Commons Attribution License, which permits unrestricted use, distribution, and reproduction in any medium, provided the original work is properly cited.

Quick decline is one of the deadly diseases of mango (Mangifera indica) which causes a serious damage to the tree and its production. In the current study, we examined the levels of important phytochemicals and minerals in the stem bark of healthy and infected mango tree. Infected stem bark showed 12.5\% lower levels of total sugars and 51.1\% higher levels of proteins as compared to healthy parts, whereas no variation was observed in reducing sugar, free amino acid, and ascorbic acid. Among micronutrients, the levels of $\mathrm{Zn}, \mathrm{Na}, \mathrm{Cr}$, and $\mathrm{Cl}$ were lowered by $25 \%, 54.3 \%, 25 \%$, and $75.4 \%$, respectively, whereas the level of Ni was $62.5 \%$ higher in the infected stem bark when compared with the healthy stem bark. However, other micronutrients did not show significant differences between healthy and infected parts. Among macronutrients, the quantity of N, P, and Mg showed an increase of 51.2\%, 34.7\%, and $27.6 \%$, respectively, whereas the quantity of $\mathrm{Ca}$ and $\mathrm{K}$ was decreased by $25.2 \%$ and $7.66 \%$ in the infected stem barks as compared to healthy ones. The results of this study provide some basic but important information that may ultimately be helpful in managing the quick decline disease in the mango trees.

\section{Introduction}

Mango (Mangifera indica) belonging to family Anacardiaceae is an important delicious fruit tree of tropical and subtropical regions of the world, known as the king of all fruits $[1,2]$. It is grown in Pakistan, India, China, Mexico, Bangladesh, Thailand, Philippine, Indonesia, Nigeria, Brazil, Florida, and Oman. Mango is an important export of Pakistan. It is exported to many countries including England, Saudi Arabia, UAE, Germany, France, Holland, Thailand, Bangladesh, Singapore, Italy, and Malaysia. Several varieties of mango are grown in Pakistan on over 94.1 thousand hectares' area with a production of about 916.8 thousand tons [3].

Various diseases affect mango yield all over the world. Its production in Pakistan has decreased due to numerous biotic and abiotic factors. Comparatively new disease of mango orchard known as the "quick decline" or "sudden death" is damaging mango trees $[4,5]$. Besides many other countries, mango decline is becoming a serious problem also in Pakistan [4] and Oman [6]. Some visible symptoms of quick decline include bark splitting, gummosis, streaking, and vascular discoloration. Leaves of the diseased tree dry up but remain attached to the dying tree. The infected trunk on scrapping oozes badly smelling liquid [7]. The diseased tree usually dies due to blockage in the proper flow of nutrients in xylem and phloem vascular bundles [8].

Both biotic and abiotic factors are responsible for the quick decline of mango trees. Among biotic factors, different researchers have reported various fungi, namely, Lasiodiplodia theobromae, Botryodiplodia ribis, Fusarium equiseti, Alternaria alternata, Dothiorella dominicana, Hendersonula toruloidea, Physalospora rhodina, Colletotrichum gloeosporioides, Rhizoctonia solani, Pestalotia mangiferae, Diplodia sp., Colletotrichum sp., Curvularia sp., and Oidium sp., Phomopsis 
sp., Sclerotium rolfsii, and Fusarium solani [9]. The abiotic factors such as humidity, high temperature, sun scold, water stress and drought, unskilled cultural practices, and less attention by the farmers and growers also contribute to the development of quick decline disease [10].

Plant cells contain a variety of substances which are involved in resistance or susceptibility to infection by pathogens. These substances include protein, phenols, ascorbic acid, amino acid, tannins, flavonoids, alkaloids, and sugar $[11,12]$. Mineral nutrients are critical for the growth and defence of plants which play an important role in plantdisease interactions. Composition of nutrients in a plant may affect disease susceptibility through metabolic changes and may affect the plant's vascular system by impairing the nutrient or water translocation, potentially leading to wilting, root starvation, and plant decline or death [13].

The objective of the present study was to examine the effect of quick decline on the phytochemical and mineral composition of the infected and healthy parts of the plant suffering from quick decline disease. We hypothesized that the quick decline disease disturbs the levels of biochemical and mineral contents of the tree as a result of host-pathogen interaction. The results of this study provide useful information for developing strategies to manage mango quick decline disease in future.

\section{Materials and Methods}

2.1. Sample Collection and Storage. Samples from infected and healthy stem bark of $M$. indica suffering from quick decline were collected from experimental orchards of Mango Research Station, Shujabad, Punjab (Pakistan). The samples were washed in distilled water, shade-dried, subsequently milled in an electronic grinder, and powdered. The powdered materials were stored in screw-capped plastic jars for further analysis.

2.2. Sample Preparation and Minerals Analysis. Analytical methods require decomposition of plant material for trace elemental analysis [14]. The sample is converted into liquid form for analysis using an inductively coupled plasma-optical emission spectrometry (ICP-OES) which was achieved by destruction of organic material through wet or dry oxidation. Samples $\left(2 \mathrm{~g}\right.$ each) were ashed at $500^{\circ} \mathrm{C}$ for $5 \mathrm{~h}$ in a muffle furnace. The ash contents were dissolved in aqua regia. For determinations of $\mathrm{Al}, \mathrm{B}$, and $\mathrm{Se}$, samples (1 $\mathrm{g}$ each) were dissolved in a mixture of $\mathrm{HNO}_{3}-\mathrm{HCLO}_{4}$ in Teflon apparatus. Analyses of Al, B, and Se were carried out with wet digestion method while the rest of the minerals analyses were carried out with dry-ashing digestion method. Control samples for both digestion methods were prepared in parallel for subtraction in the spectrometric determinations. Each sample had three replicates. The elemental concentrations in all samples were measured by using ICP-OES (Perkin Elmer) using standard methods. The operating conditions of the instrument and wavelength ranges of elements were followed as per reported literature and instrument manufacturer instructions. Absorbance values of each element were expressed as the mean value of three determinations (relative standard deviation). $\mathrm{Na}$ and $\mathrm{K}$ contents were determined by Flame Photometry (Jenway PFP7) under conditions specified by the manufacturer.

2.3. Phosphorus and Nitrogen Analysis. The digest prepared by wet ashing was used for analysis of phosphorus. Phosphorus content of the digest was determined colorimetrically according to the reported methods $[15,16]$. Nitrogen contents were determined by Kjeldahl method according to the reported literature with some modifications $[17,18]$.

2.4. Total Ash. Dry powdered sample (1 g) was weighed into a porcelain crucible and incinerated in a muffle furnace at $500^{\circ} \mathrm{C}$ for $5 \mathrm{~h}$. The ash contents were weighed, cooled in a desiccator, and weighed. Then water soluble and insoluble ash contents were determined and given in Table S4, in Supplementary Material available online at http://dx.doi.org/ 10.1155/2016/8219356.

2.5. Total Flavonoids Analysis. Total flavonoids content was determined by following already established method [19] with little modification. $0.5 \mathrm{~mL}$ of sample extract $(1 \mathrm{mg} / \mathrm{mL})$ was mixed with $2 \mathrm{~mL}$ of distilled water and then $0.15 \mathrm{~mL}$ of $\mathrm{NaNO}_{2}(5 \%)$ solution. Samples were incubated for 6 minutes at room temperature and then $0.15 \mathrm{~mL}$ of $\mathrm{AlCl}_{3}$ (10\%) was added. The samples were allowed to stand for 6 minutes, and $2 \mathrm{~mL}$ of $\mathrm{NaOH}(4 \%)$ were added to the mixture. The final volume was made up to $5 \mathrm{~mL}$ with methanol and mixed well. The mixture was allowed to stand for $15 \mathrm{~min}$ and spectrophotometric absorbance was recorded at $510 \mathrm{~nm}$ using UV/ Visible Spectrophotometer (Jenway-6405). The total flavonoid contents were expressed in milligrams of catechin equivalent per gram of extract.

2.6. Assay for Total Phenols. The amount of total phenolics content in extract was determined according to FolinCiocalteu method [20] with slight modification. Briefly, $1 \mathrm{~mL}$ of extract solution and $1 \mathrm{~mL}$ of Folin-Ciocalteu reagent were added and the contents were mixed vigorously. After shaking for $4 \mathrm{~min}, 1 \mathrm{~mL}$ of $15 \% \mathrm{Na}_{2} \mathrm{CO}_{3}$ was added and the mixture was allowed to stand for 2 hours at room temperature. The absorbance of samples was noted at $725 \mathrm{~nm}$. The concentration of the total phenolics was estimated as mg of gallic acid equivalent by using an equation obtained from gallic acid calibration curve.

2.7. Alkaloid Determination. Alkaloid determination was carried out by using method of Harborne [21]. $5 \mathrm{~g}$ of the sample was mixed with $200 \mathrm{~mL}$ of $20 \%$ acetic acid in ethanol. The mixture was allowed to stand at room temperature for $4 \mathrm{~h}$. An extract was prepared and concentrated ammonium hydroxide was added slowly until the precipitation was completed. The whole solution was allowed to settle down and the precipitate was collected by filtration and weighed.

2.8. Tannin Determination. Tannin contents were determined by the method of Van Buren and Robinson [22]. $0.5 \mathrm{~g}$ of the sample was taken into $100 \mathrm{~mL}$ plastic bottle. $50 \mathrm{~mL}$ of distilled water was added. The samples were shaken for $1 \mathrm{~h}$ in a mechanical shaker. This mixture was filtered into a $50 \mathrm{~mL}$ 
volumetric flask and made up to the mark. $5 \mathrm{~mL}$ of the filtrate was transferred into a tube and mixed with $3 \mathrm{~mL}$ of $0.1 \mathrm{M}$ $\mathrm{FeCl}_{3}$ in $0.1 \mathrm{~N} \mathrm{HCl}$ and $0.008 \mathrm{M}$ potassium ferrocyanide. After $10 \mathrm{~min}$, absorbance was recorded at $120 \mathrm{~nm}$. A blank sample was also prepared and absorbance was recorded at the same wavelength. A standard was prepared using tannin acid to get $100 \mathrm{ppm}$ and measured.

2.9. Extraction and Analysis of Sugars, Free Amino Acids, and Ascorbic Acid. Analyses of sugars and free amino acids were done by following method of Shad and colleagues [23]. Ethanol extract was used for quantitative analysis of sugars, free amino acid, and ascorbic acid contents. Total sugars were determined using anthrone reagent by following method of Travelyan and colleagues [24]. Reducing sugars were determined by ferricyanide method by following method of Hulme and Narain [25]. Free amino acids and ascorbic acid contents were determined by adopting established method [26].

2.10. Statistical Analysis. Statistical analyses were performed with OriginPro 2016 (Origin Lab, Northampton, MA). Each experiment was repeated for at least three times. Normality of each sample (i.e., if a sample came from a normally distributed population) was assessed by Shapiro-Wilk test. Student's $t$-tests were performed between infected and healthy samples with $p<0.05$ considered statistically significant. Results expressed as mean \pm SD are shown by bar graphs.

\section{Results and Discussion}

Plant diseases are one of the major problems being faced by the agriculture sector across the globe. Understanding the defence mechanisms of plants against pathogens may help to develop new strategies against various diseases in crop plants [27]. Plant defence responses are controlled by a complex network of regulators which include signal molecules and transcription factors. Plant resistance genes activate mechanism for specific recognition of pathogens and initiate defence responses $[28,29]$. The fungal infections induce morphologi$\mathrm{cal}$ and biochemical changes in plants. Fungal infections also affect the normal metabolism of plants along with causing the oxidative and hydrolytic reaction imbalances [30].

In order to check the effect of quick decline, we analyzed the levels of minerals, biochemicals, and some important phytochemicals (tannin, alkaloids, phenol, and flavonoids) from infected stem and healthy stem bark of mango tree.

3.1. Primary Metabolites. Fungus-infected stem bark had lower levels of total sugars but higher levels of protein contents than the healthy counterparts $(p<0.05)$ while no significant variation was seen in free amino acids, ascorbic acid, and reducing sugar contents (Figure 1 and Table S1). Decrease in the total sugar contents may possibly be due to the decrease in the rate of anabolism (photosynthesis) or elevated rate of degradation of sugars in the infected parts caused by the pathogen [23]. Soluble sugars respond to a number of stresses. They act as metabolite signaling molecules that activate specific hormonal-cross talk transduction pathways, resultantly bringing important modifications in gene expression.

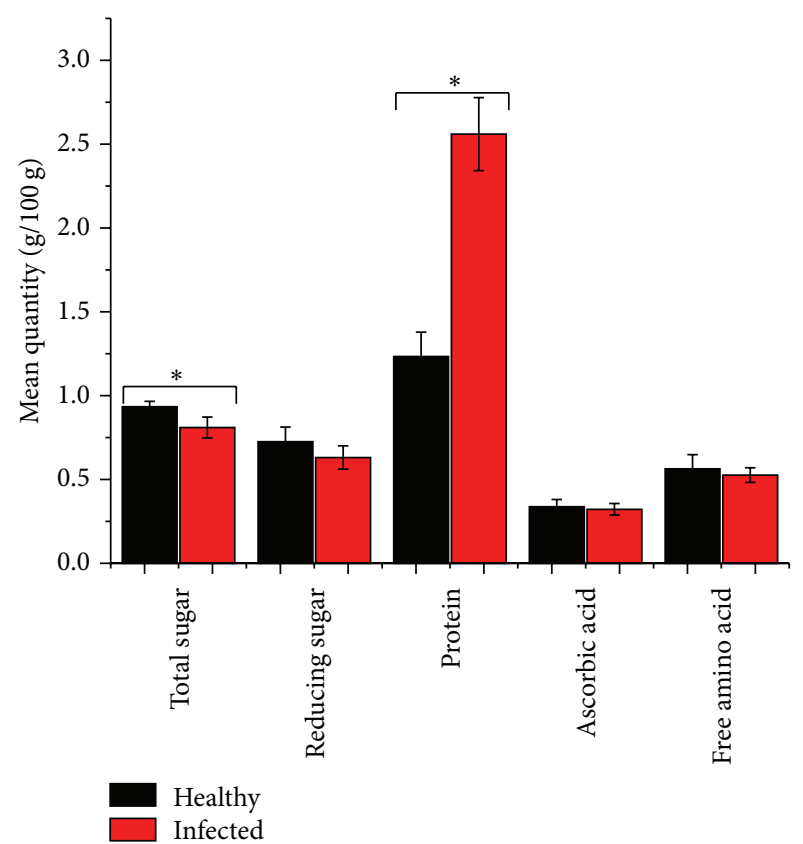

FIGURE 1: Quantification of primary metabolites (g/100 g) in healthy and infected stem bark of mango suffering from quick decline disease. Each bar represents mean \pm SD contents of the specific primary metabolite as indicated. $*$ indicates that there was a statistically significant difference between healthy and infected sample at $95 \%$ CI.

Proteins are not broken down into amino acids possibly due to less proteolytic enzyme activity in the infected bark [31].

3.2. Secondary Metabolites. Fungal infection induces phenolic compounds in plants [32] and it is found that they give resistance to plants against certain fungal pathogens [33]. Our study revealed higher level of phenols in infected stem barks compared to the healthy ones. However, this difference was not statistically significant. Total phenol contents $(0.30 \pm$ $0.089 \mathrm{~g} / 100 \mathrm{~g}$ ) in infected stem bark were higher compared to healthy stem bark $(0.22 \pm 0.062 \mathrm{~g} / 100 \mathrm{~g})$. Some researchers noted an increase in the amount of phenolic substances in various host-pathogen interactions after infection [34]. Tannins, alkaloids, and flavonoids showed no statistically significant differences between infected and healthy parts. Tannins in healthy stem bark $(0.74 \pm 0.089 \mathrm{~g} / 100 \mathrm{~g})$ were relatively higher compared to infected stem bark $(0.58 \pm 0.062 \mathrm{~g} / 100 \mathrm{~g})$. Flavonoid contents in infected stem bark $(0.46 \pm 0.089 \mathrm{~g} / 100 \mathrm{~g})$ were relatively higher compared to healthy stem bark $(0.38 \pm$ $0.07 \mathrm{~g} / 100 \mathrm{~g}$ ). Alkaloids concentration was relatively lower in infected stem bark $(0.19 \pm 0.062 \mathrm{~g} / 100 \mathrm{~g})$ compared to the healthy stem bark $(0.26 \pm 0.082 \mathrm{~g} / 100 \mathrm{~g})$. The detailed results are shown in Figure 2 and Table S2.

3.3. Minerals. The minerals are important part of the plant normal physiology [35]. The plants have tendency to accumulate some of the minerals $(\mathrm{Cd}, \mathrm{Co}$, and $\mathrm{Ag}$ ) which are not necessary for their survival [36]. However, some minerals $(\mathrm{N}, \mathrm{P}, \mathrm{K}, \mathrm{Ca}, \mathrm{Zn}$, and $\mathrm{Mn})$ are critical for plants and their imbalance may lead to disease development. Microbial 


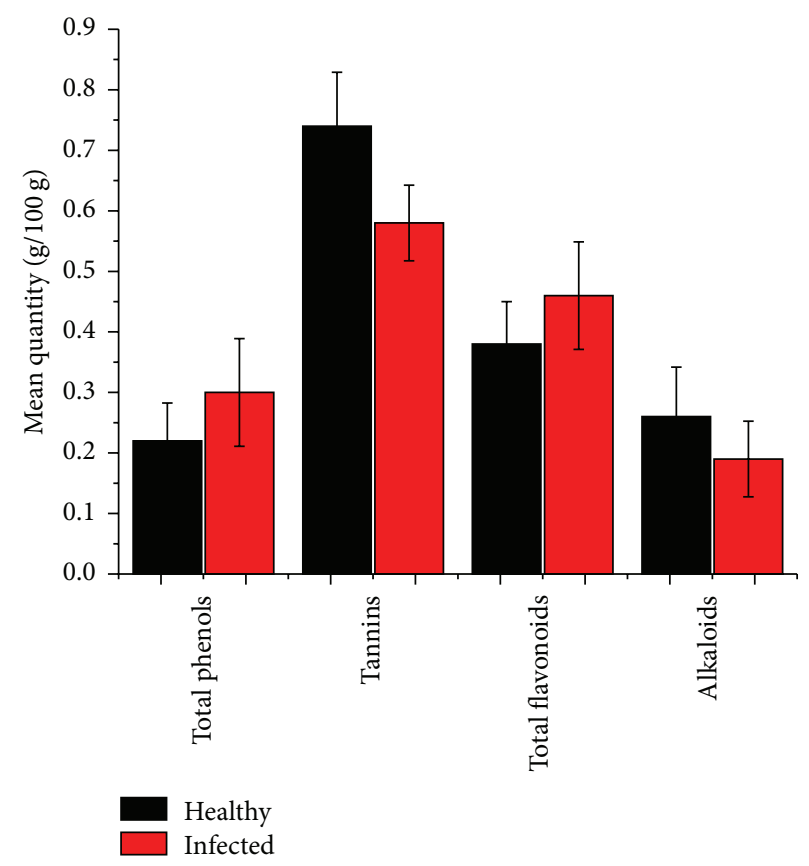

FIGURE 2: Quantification of secondary metabolites (g/100 g) in healthy and infected stem bark of mango suffering from quick decline disease. Each Bar represents mean \pm SD contents of the specific secondary metabolite as indicated.

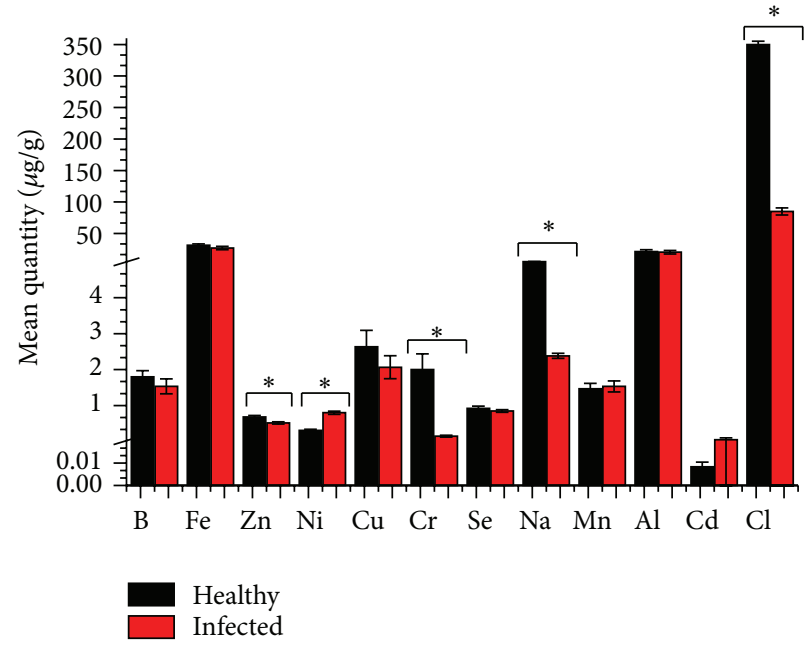

(a)

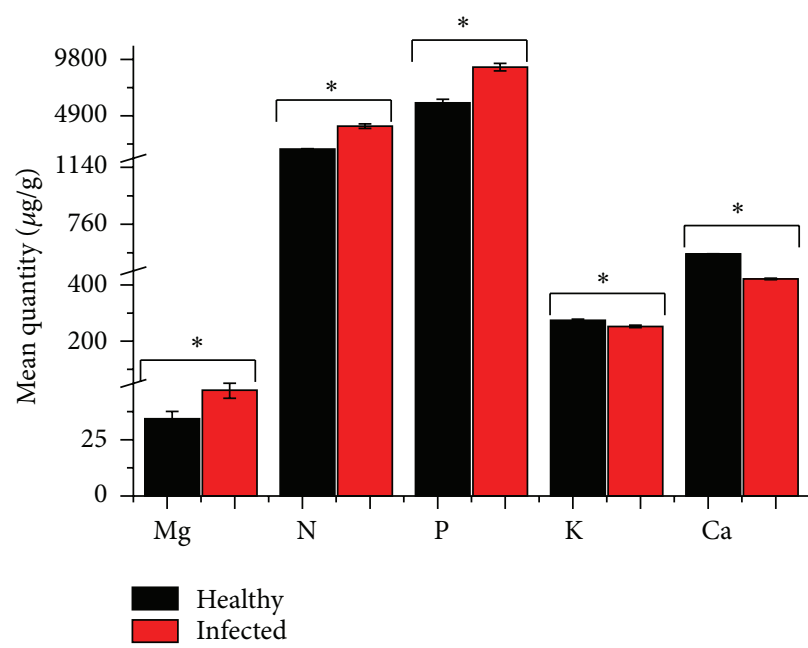

(b)

FiguRE 3: Quantification of mineral contents $(\mu \mathrm{g} / \mathrm{g})$ in healthy and infected stem bark of mango suffering from quick decline disease. Each bar represents mean \pm SD contents of the specific mineral as indicated. $*$ indicates that there was a significant difference between healthy and infected sample at $95 \% \mathrm{CI}$.

interactions with plant roots have been reported to have adverse effects on plant nutrient status [37].

Our results (Figure 3 and Table S3) revealed that quick decline markedly increased the $\mathrm{N}, \mathrm{P}$, and $\mathrm{Mg}$ contents whereas the disease significantly reduced the contents of $\mathrm{K}$ and Ca. Decrease in Ca and $\mathrm{K}$ quantity in infected tissues might be linked to the fungal toxins affecting $\mathrm{K}$ uptake and stomata function leading to uncontrolled transpiration, excessive loss of water, and finally wilted plants [38]. An adequate K supply dose promotes cell wall thickening that helps the plant to resist disease. Calcium under Fusarium oxysporum pathogenesis may interfere with the uptake of toxic ions from the soil [39].

Results also showed that infected stem bark had higher levels of Ni contents compared to healthy bark. Zn contents in infected stem bark were lower compared to healthy stem bark. Among other micronutrients $\mathrm{Zn}$ can increase resistance in plants to pathogen $[40,41]$. When zinc is applied as a root dip prior to transplant or as a soil amendment, it reduces the incidence of root disease in rice and wilt disease in cotton [42]. 
Lower manganese contents in infected stem bark indicate that quick decline disease has blocked the supply of manganese to plant trunk. Manganese may prove to be one of the most important factors in the development of resistance of plants to both root and foliar diseases of fungal origin [43].

Some unwanted elements were also observed $(\mathrm{Pb}, \mathrm{Cd}$, and $\mathrm{Na}$ ) during analysis. These might be a contributing factor along with fungal infection for the decline of mango plant. In our study, the level of aluminum did not differ between the healthy and infected stem bark. The level of lead in infected stem bark was below detection limit. The molybdenum concentration was below detection limit in all samples (Table S3). Metals which are usually considered nonessential $(\mathrm{Pb}, \mathrm{Cd}$, $\mathrm{Cr}$, etc.) may potentially be highly toxic to plants [44-46]. Urbanization, industrialization, and agricultural practices have contaminated a huge area of land with heavy metals (the main group of inorganic contaminants) [47, 48]. Excess of trace elements ( $\mathrm{Cd}, \mathrm{Cr}, \mathrm{Mn}, \mathrm{Ni}, \mathrm{Pb}$, and $\mathrm{Zn}$ ) being toxic may cause growth inhibition, biomass reduction, and plant death [49]. Heavy metals also interfere with the normal physiological processes such as respiration, photosynthesis, cell elongation, plant-water relationship, and metabolism [50].

3.4. Ash Contents. Ash refers to the inorganic residue (minerals) after the water and organic matter have been removed. This is achieved by either ignition or complete oxidation of organic matter. As discussed earlier, the mineral contents are important in various plant processes. Our results showed that ash contents were significantly higher in infected bark compared to the healthy bark. The detailed results of ash contents are shown in Figure 4 and Table S4.

\section{Conclusions}

Higher amount of total sugar was found in healthy stem bark compared to infected stem bark while higher level of protein was found in infected stem bark compared to healthy stem bark. This study showed varying trends of biochemical concentrations in infected and healthy parts. The utilization of biochemicals by disease-causing pathogens or their degradation by certain secreted metabolites in infected plants has been suggested to cause the observed depletion [51] and other studies have also reported similar observations [52, 53]. On the other side, due to pathogen infection, biochemical constituents were found to be accumulated in the plants [54, 55]. Tannins and alkaloids were in relatively higher amount in healthy stem bark compared to infected stem bark, while total phenol and flavonoids contents were relatively higher in infected stem bark compared to healthy stem bark. Analysis of minerals and primary and secondary metabolites was important for determining the nutritional status of mango stem bark after infection.

M. indica have great economic importance for Pakistan. By controlling quick decline disease, substantial loss of revenue to the nation can be prevented. Quick decline disease is probably due to soil contamination and/or airborne spores produced from the infected plants. Thus, improvement in plant nutrition by introduction of manures and fertilizers may enhance plant development and also might make the

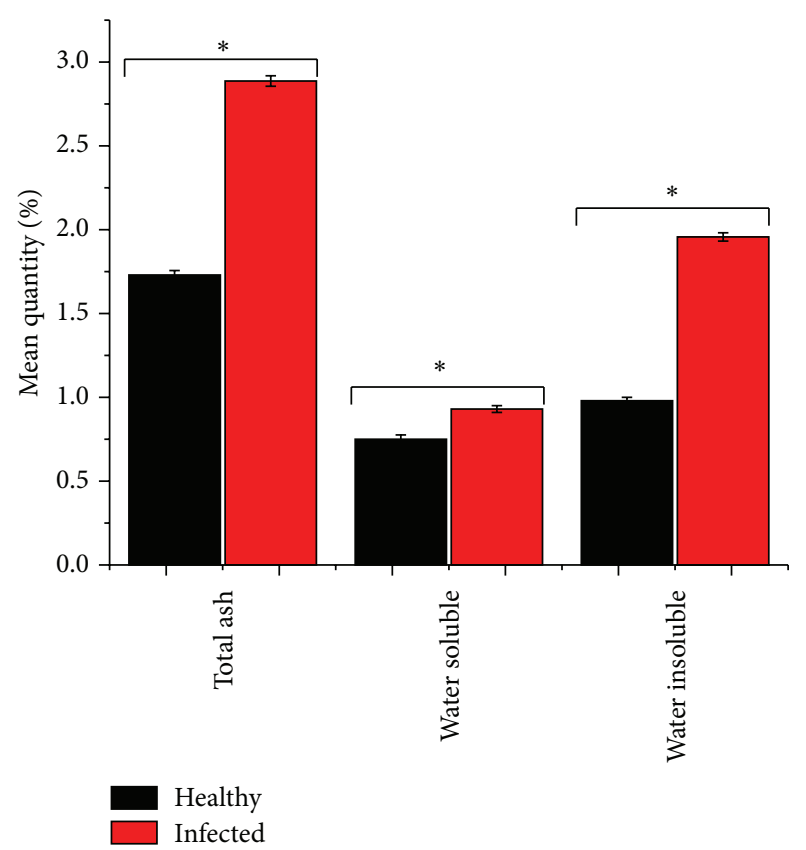

FIGURE 4: Quantification of ash contents (\%) in healthy and infected stem bark of mango suffering from quick decline disease. Each bar represents mean \pm SD contents of the specific ash as indicated. * indicates that there was a statistically significant difference between healthy and infected sample at 95\% CI.

plant more resistant to or compensate for the effect of disease. The other effective measure can be the use of biochemical profile information to manage quick decline, that is, by using pathogen tolerant varieties and effective use of fungicides.

\section{Competing Interests}

The authors declare that they have no competing interests.

\section{Acknowledgments}

The authors appreciate the assistance of Dr. Zahid Mehmood, Director Central Cotton Research Institute, Multan, for provision of analytical facilities.

\section{References}

[1] R. E. Litz, The Mango: Botany, Production and Uses, CABI, 2009.

[2] A. Sial, "Mango: a fruit for the world market," Business of Finance Review, The News, pp. 17-19, 2002.

[3] M. Jiskani, Dying of Mango Orchards Needs Special Attention, Sindh Agriculture University, Tando Jam, Pakistan, 2002.

[4] M. Malik, S. Khan, A. Dasti, and M. Kazmi, "First record of Ceratocystis fimbriata, causal organism of mango sudden death in Pakistan," Pakistan Journal of Phytopathology, vol. 17, pp. 187191, 2005

[5] R. C. Ploetz, D. Benscher, A. Vázquez, A. Colls, J. Nagel, and B. Schaffer, "A reexamination of mango decline in Florida," Plant Disease, vol. 80, no. 6, pp. 664-668, 1996.

[6] A. O. Al Adawi, M. L. Deadman, A. K. Al Rawahi et al., "Aetiology and causal agents of mango sudden decline disease in the 
Sultanate of Oman," European Journal of Plant Pathology, vol. 116, no. 4, pp. 247-254, 2006.

[7] A. Masood, S. Saeed, N. Iqbal, M. T. Malik, and M. R. Kazmi, "Methodology for the evaluation of symptoms severity of mango sudden death syndrome in Pakistan," Pakistan Journal of Botany, vol. 42, no. 2, pp. 1289-1299, 2010.

[8] R. Khuhro, S. Nizamani, Q. Abbasi, G. Solangi, and M. Jiskani, "Mango tree mortality due to Asian ambrosia beetle, Xylosandrus crassiusculus Mot.(Coleoptera: Scolytidae)," Pakistan Journal of Agriculture, Agricultural Engineering, Veterinary Sciences, vol. 21, pp. 39-42, 2005.

[9] M. A. Khanzada, A. M. Lodhi, and S. Shahzad, "Pathogenicity of Lasiodiplodia theobromae and Fusarium solani on mango," Pakistan Journal of Botany, vol. 36, no. 1, pp. 181-189, 2004.

[10] M. Kazmi, F. Fateh, K. Majeed et al., "Incidence and etiology of mango sudden death phenomenon in Pakistan," Pakistan Journal of Phytopathology, vol. 17, no. 2, pp. 154-158, 2005.

[11] P. Vidhyasekaran, Fungal Pathogenesis in Plants and Crops: Molecular Biology and Host Defense Mechanisms, CRC Press, 2007.

[12] G. N. Agrios, Plant Pathology, Academic Press, New York, NY, USA, 2005.

[13] T. Spann and A. Schumann, Mineral Nutrition Contributes to Plant Disease and Pest Resistance, IFAS Extension HS1181, University of Florida, Gainesville, Fla, USA, 2010.

[14] G. Tolg, "The basis of trace analysis," in Methodium Chimicuin, vol. 1, pp. 698-710, Academic Press, New York, NY, USA, 1974.

[15] A. Nahapetian and A. Bassiri, "Changes in concentrations and interrelations of phytate, phosphorus, magnesium, calcium, and zinc in wheat during maturation," Journal of Agricultural and Food Chemistry, vol. 23, no. 6, pp. 1179-1182, 1975.

[16] F. Shahidi, U. D. Chavan, A. K. Bal, and D. B. McKenzie, "Chemical composition of beach pea (Lathyrus maritimus L.) plant parts," Food Chemistry, vol. 64, no. 1, pp. 39-44, 1999.

[17] N. J. Thiex, H. Manson, S. Anderson, and J.-Å. Persson, "Determination of crude protein in animal feed, forage, grain, and oilseeds by using block digestion with a copper catalyst and steam distillation into boric acid: collaborative study," Journal of AOAC International, vol. 85, no. 2, pp. 309-317, 2002.

[18] J. Ryan, G. Estefan, and A. Rashid, Soil and Plant Analysis Laboratory Manual, ICARDA, 2007.

[19] C.-C. Chang, M.-H. Yang, H.-M. Wen, and J.-C. Chern, "Estimation of total flavonoid content in propolis by two complementary colometric methods," Journal of Food and Drug Analysis, vol. 10, no. 3, pp. 178-182, 2002.

[20] M. A. Hossain, M. D. Shah, C. Gnanaraj, and M. Iqbal, "In vitro total phenolics, flavonoids contents and antioxidant activity of essential oil, various organic extracts from the leaves of tropical medicinal plant Tetrastigma from Sabah," Asian Pacific Journal of Tropical Medicine, vol. 4, no. 9, pp. 717-721, 2011.

[21] J. A. Harborne, Phytochemical Methods. A Guide to Modern Techniques of Plant Analysis, Springer, 1998.

[22] J. P. Van Buren and W. B. Robinson, "Formation of complexes between protein and tannic acid," Journal of Agricultural and Food Chemistry, vol. 17, no. 4, pp. 772-777, 1969.

[23] M. A. Shad, T. M. Ansari, H. P. Pervez, M. R. Rubab, and T. M. Mahmood, "Changes in sugar, amino acid and mineral contents of leaves of two mango varieties affected by quick decline disease," Journal of Biological Sciences, vol. 2, no. 10, pp. 694696, 2002.
[24] W. E. Trevelyan, R. S. Forrest, and J. S. Harrison, "Determination of yeast carbohydrates with the anthrone reagent," Nature, vol. 170, no. 4328, pp. 626-627, 1952.

[25] A. C. Hulme and R. Narain, "The ferricyanide method for the determination of reducing sugars: a modification of the Hagedorn-Jensen-Hanes technique," Biochemical Journal, vol. 25, no. 4, pp. 1051-1061, 1931.

[26] D. K. Asami, Y.-J. Hong, D. M. Barrett, and A. E. Mitchell, "Comparison of the total phenolic and ascorbic acid content of freeze-dried and air-dried marionberry, strawberry, and corn grown using conventional, organic, and sustainable agricultural practices," Journal of Agricultural and Food Chemistry, vol. 51, no. 5, pp. 1237-1241, 2003.

[27] M. J. Pozo, L. C. Van Loon, and C. M. J. Pieterse, "Jasmonatessignals in plant-microbe interactions," Journal of Plant Growth Regulation, vol. 23, no. 3, pp. 211-222, 2004.

[28] M. Martínez-Ferrer and C. Harper, "Reduction in microbial growth and improvement of storage quality in fresh-cut pineapple after methyl jasmonate treatment," Journal of Food Quality, vol. 28, no. 1, pp. 3-12, 2005.

[29] M. J. Stout, K. V. Workman, R. M. Bostock, and S. S. Duffey, "Stimulation and attenuation of induced resistance by elicitors and inhibitors of chemical induction in tomato (Lycopersicon esculentum) foliage," Entomologia Experimentalis et Applicata, vol. 86, no. 3, pp. 267-279, 1998.

[30] F. Nonaka, "On the relation between the stem rot caused by Leptosphaeria salvinii and the rice nematode disease, white tip, and on the changes of the respiration rate and activities of respiratory enzymes of the white tip plants," Science Bulletin of the Faculty of Agriculture, Kyushu University, vol. 17, no. 1, p. 8, 1959.

[31] R. K. Howell and L. R. Krusberg, "Changes in concentrations of nitrogen and free and bound amino acids in alfalfa and pea infected by Ditylenchus dipsaci," Phytopathology, vol. 56, no. 10, pp. 1170-1177, 1966.

[32] R. L. Nicholson and R. Hammerschmidt, "Phenolic compounds and their role in disease resistance," Annual Review of Phytopathology, vol. 30, no. 1, pp. 369-389, 1992.

[33] J. C. Walker and M. A. Stahmann, "Chemical nature of disease resistance in plants," Annual Review of Plant Physiology, vol. 6, no. 1, pp. 351-366, 1955.

[34] V. Lattanzio, V. M. T. Lattanzio, and A. Cardinali, "Role of phenolics in the resistance mechanisms of plants against fungal pathogens and insects," in Phytochemistry: Advances in Research, F. Imperato, Ed., pp. 23-67, Research Signpost, Trivandrum, India, 2006.

[35] S. Clemens, M. G. Palmgren, and U. Krämer, "A long way ahead: understanding and engineering plant metal accumulation," Trends in Plant Science, vol. 7, no. 7, pp. 309-315, 2002.

[36] A. M. O. Ajasa, M. O. Bello, A. O. Ibrahim, I. A. Ogunwande, and N. O. Olawore, "Heavy trace metals and macronutrients status in herbal plants of Nigeria," Food Chemistry, vol. 85, no. 1, pp. 67-71, 2004.

[37] E. Nafie, "The possible induction of resistance in Lupinus termis L. against Fusarium oxysporum by Streptomyces chibaensis and its mode of action: I. Changes in certain morphological criteria and biochemical composition related to induced resistance," International Journal of Agriculture and Biology, vol. 5, pp. 463472, 2003.

[38] I. Heiser, W. Oßwald, and E. F. Elstner, "The formation of reactive oxygen species by fungal and bacterial phytotoxins," Plant Physiology and Biochemistry, vol. 36, no. 10, pp. 703-713, 1998. 
[39] D. M. Orcutt and E. T. Nilsen, The Physiology of Plants under Stress: Soil and Biotic Factors, John Wiley \& Sons, New York, NY, USA, 2000.

[40] A. R. Hardham, "Cell biology of pathogenesis," Annual Review of Plant Physiology and Plant Molecular Biology, vol. 43, no. 1, pp. 491-526, 1992.

[41] K. Shirasu, T. Lahaye, M.-W. Tan, F. Zhou, C. Azevedo, and P. Schulze-Lefert, "A novel class of eukaryotic zinc-binding proteins is required for disease resistance signaling in barley and development in C. elegans," Cell, vol. 99, no. 4, pp. 355-366, 1999.

[42] G. Agrios, Plant Pathology, Academic Press, New York, NY, USA, 3rd edition, 1988.

[43] C. Altomare, W. A. Norvell, T. Björkman, and G. E. Harman, "Solubilization of phosphates and micronutrients by the plantgrowth-promoting and biocontrol fungus Trichoderma harzianum Rifai 1295-22," Applied and Environmental Microbiology, vol. 65, no. 7, pp. 2926-2933, 1999.

[44] L. Sebastiani, F. Scebba, and R. Tognetti, "Heavy metal accumulation and growth responses in poplar clones Eridano (Populus deltoides x maximowiczii) and I-214 (P. x euramericana) exposed to industrial waste," Environmental and Experimental Botany, vol. 52, no. 1, pp. 79-88, 2004.

[45] S. R. Devi and M. N. V. Prasad, "Copper toxicity in Ceratophyllum demersum L. (Coontail), a free floating macrophyte: response of antioxidant enzymes and antioxidants," Plant Science, vol. 138, no. 2, pp. 157-165, 1998.

[46] V. Rai, P. Vajpayee, S. N. Singh, and S. Mehrotra, "Effect of chromium accumulation on photosynthetic pigments, oxidative stress defense system, nitrate reduction, proline level and eugenol content of Ocimum tenuiflorum L.," Plant Science, vol. 167, no. 5, pp. 1159-1169, 2004.

[47] A. G. Khan, C. Kuek, T. M. Chaudhry, C. S. Khoo, and W. J. Hayes, "Role of plants, mycorrhizae and phytochelators in heavy metal contaminated land remediation," Chemosphere, vol. 41, no. 1-2, pp. 197-207, 2000.

[48] S. Clemens, "Molecular mechanisms of plant metal tolerance and homeostasis," Planta, vol. 212, no. 4, pp. 475-486, 2001.

[49] M. H. Zenk, "Heavy metal detoxification in higher plants-a review," Gene, vol. 179, no. 1, pp. 21-30, 1996.

[50] P. Zornoza, S. Vázquez, E. Esteban, M. Fernández-Pascual, and R. Carpena, "Cadmium-stress in nodulated white lupin: strategies to avoid toxicity," Plant Physiology and Biochemistry, vol. 40, no. 12, pp. 1003-1009, 2002.

[51] P. Ponmurugan and U. I. Baby, "Morphological, physiological and biochemical changes in resistant and susceptible cultivars of tea in relation to phomopsis disease," Plant Pathology Journal, vol. 6, no. 1, pp. 91-94, 2007.

[52] M. P. De Nooij and H. A. Van Der Aa, "Phomopsis subordinaria and associated stalk disease in natural populations of Plantago lanceolata," Canadian Journal of Botany, vol. 65, no. 1, pp. 23182325, 1987.

[53] G. Kaur and R. Mehrotra, "Biochemical studies of pigeonpea varieties resistant and susceptible to Phytophthora blight," Plant Disease Research, vol. 5, no. 1, pp. 122-125, 1990.

[54] W. Dhillon, A. Bindra, and S. Kapoor, "Some biochemical changes induced in powdery mildew infected grapevine leaves," Plant Disease Research, vol. 7, no. 2, pp. 248-250, 1992.

[55] B. Prasad, R. Singh, and N. Narayan, "Biochemical changes in nitrogen and carbohydrate in coriander infected with Protomyces macrosporus," Indian Phytopathology, vol. 42, no. 3, pp. 426-430, 1989. 


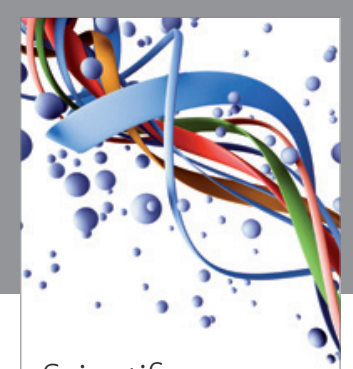

Scientifica
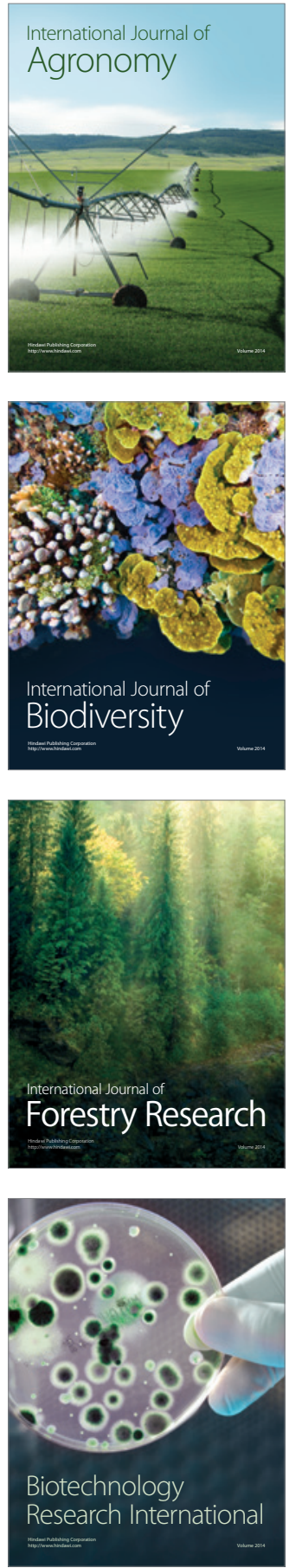
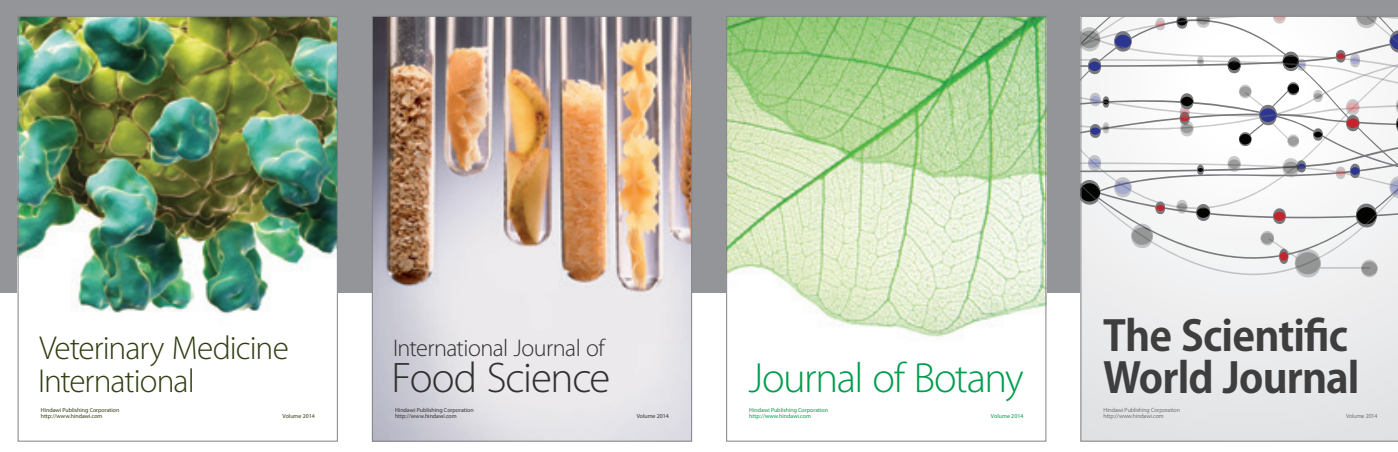

The Scientific

\section{World Journal}

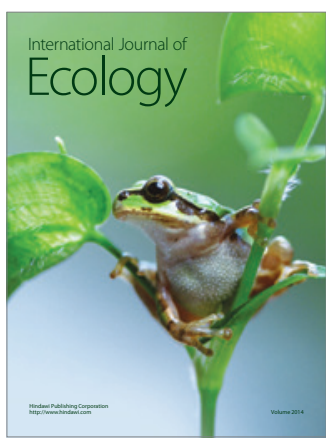

\section{Hindawi}

Submit your manuscripts at

http://www.hindawi.com
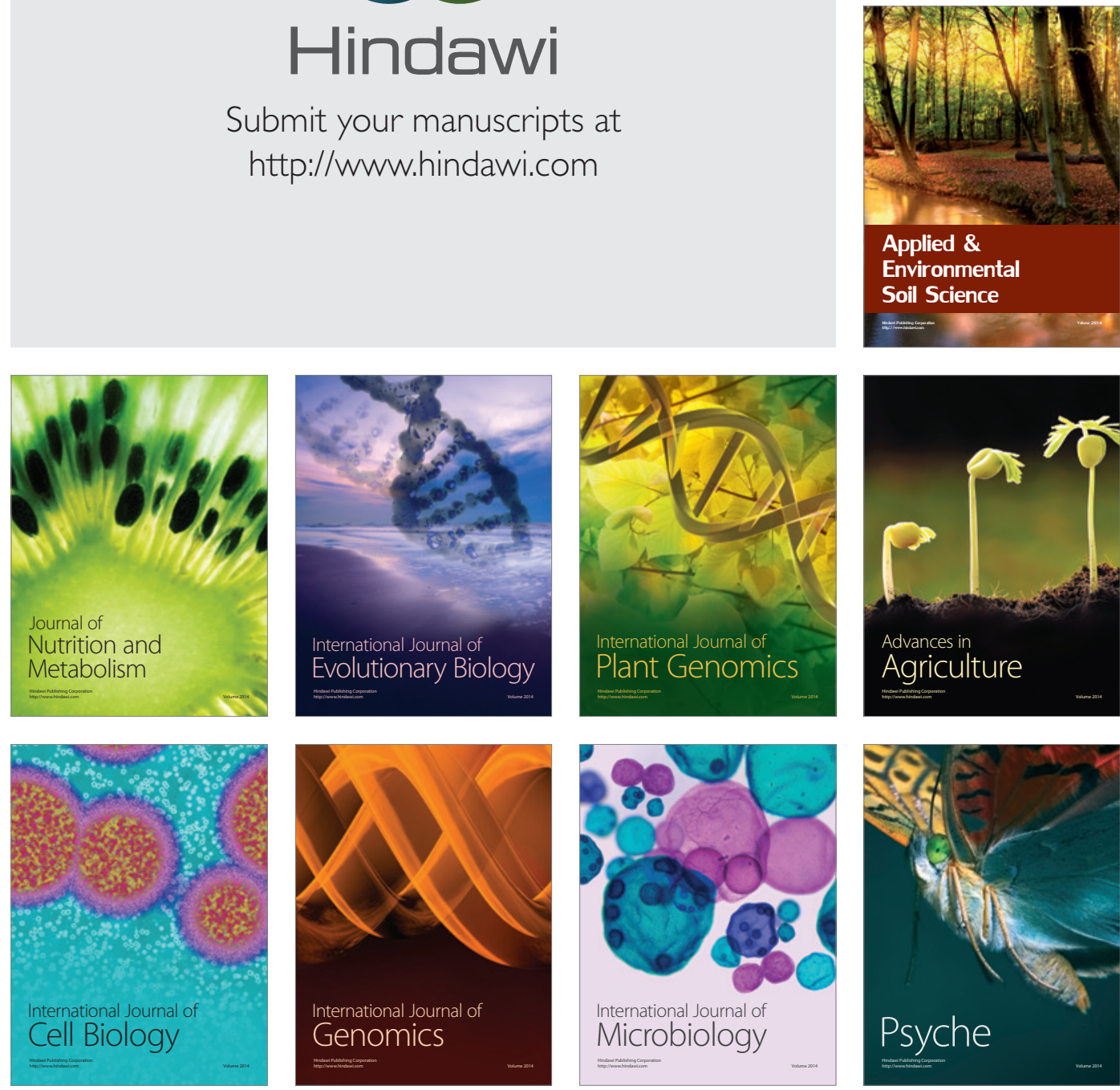
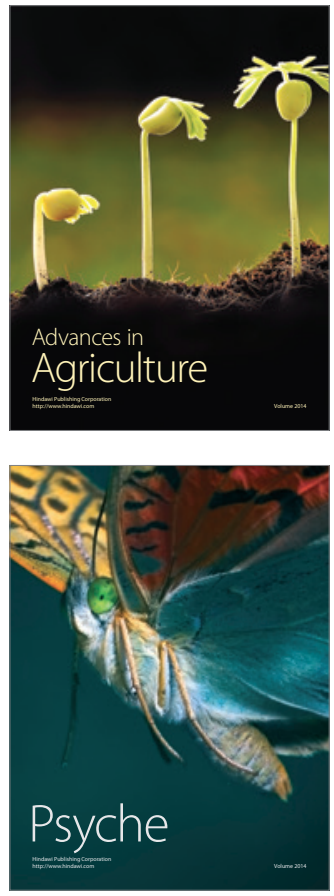